\title{
STRUCTURAL MODEL OF AN IMPERSONAL SENTENCE IN CZECH LANGUAGE
}

\section{Kalenychenko M. M.}

\section{INTRODUCTION}

In modern Slavic science, the syntactic level remains one of the least studied structural levels of Slavic languages. Many current problems of Slavic syntax, which require a thorough theoretical coverage of a number of issues related both to understanding the intra-syntactic organization of monosyllabic, including impersonal, sentences in Slavic languages, and with the problem of modeling the relevant syntactic units, unfortunately, did not find a synonymous unambiguous solution in the scientific literature.

As the analysis of the scientific literature on the researched problem shows, in modern linguistics sentence models are often analyzed without taking into account their functional characteristics ${ }^{1}$. This approach deprives syntactists of the opportunity to give an in-depth interpretation of many types of Slavic sentences, including impersonal, which are built on the same structural model, but differ in the nature of syntactic functions of components, which has been repeatedly drawn by the attention of a number of researchers.

In linguoslavistics on the basis of different Slavic languages impersonal constructions have been thoroughly studied from their formal and grammatical organization (V.V. Babaytseva, L.I. Vasilevskaya, E.M. Galkina-Fedoruk, Y.V. Lokshin, G.M. Chirva, J. Bauer, F. Danesh, W. Schmilauer, etc.). The specificity of the structural parameters of impersonal sentences in Slavic languages was observed mainly within the use of lexical and grammatical means that form the grammatical center of impersonal units, identifying their syntactic labeling, correlation with other monosyllabic communicative units, the scope of different semantic and grammatical types of individual types, as well as the frequency of their use in different styles.

\section{Impersonal sentence: the history of the study of the guestion}

Unfortunately, in modern linguistic Slavic studies there is no unambiguous generally accepted definition of an impersonal sentence, its types and kinds. If some scholars consider impersonal sentences as a

\footnotetext{
${ }^{1}$ Mluvnice češtiny. Skladba. Praha : Academia, 1987. Díl 3. S. 171-172.
} 
meaningless construction with one main member - a predicate, in the form of which the meaning of a person is not expressed and there is no indication of it in this context, then for others impersonal are such monosyllabic sentences in which the action or a state (sign) that arises or exists independently of the performer of the action or the bearer of the sign.

We consider these definitions to be insufficiently substantiated, as any action necessarily presupposes the one who generates it, its active executor, actor, the level of specificity, generalization or uncertainty of which may be different. Therefore, we should not talk about independence from the actor, or signs from the carrier, but about a special 'impersonal' representation of the action or state.

We consider the definition of the Ukrainian grammarian P.S. Dudyk is much more successful, where he calls 'impersonal' such monosyllabic sentences, the main member of which means an action or state that is thought as independent of any creative action or carrier of the state.

It will be recalled that in the history of the syntax of Slavic languages, the theory of impersonality has come under constant changes. The debatable issue is explained by different views of scientists on the essence of impersonal sentences and the principles of classification. One of the important problems of the theory was the interaction of impersonal sentences with infinitive monosyllabic sentences. At one time, this question was thoroughly studied by the Russian linguist O. Shakhmatov, who called infinitive sentences, the main member of which is the infinitive, which evokes the idea of a sign that is combined with a definite (and specifically the second) or indefinite person. Infinitive sentences of this type (subjectless) were contrasted by the scientist with impersonal sentences, existential sentences that convey the combination of sign (in the subject) and being, presence (in the predicate).

O. Shakhmatov called sentences of the first type definite-personal or indefinite-personal, considering them personal, because they express an order addressed to the 2nd person singular or plural, and the categorical expression is much greater than through the imperative mood.

O. Peshkovsky held a different point of view, who, although acknowledged that it is logically impossible to imagine activity without any relation to the figure, believed that due to the irrationality of language there was a special category (infinitive) with this meaning. E.M. Galkina-Fedoruk held the same positions, believing that the infinitive, as a form of the verb, is not complicated by the meaning of person, number and gender, is very convenient for expressing activity or state regardless of the person-figure. She suggested to cosider monosyllabic sentences without subject as impersonal, in which there is one main member - a predicate expressed by an infinitive. 
In our opinion, giving infinitive sentences signs of impersonality is not sufficiently justified, because they are structurally different from those impersonal, in which the infinitive syntactically depends on other main members. If in verb impersonal sentences the action is indicated as independent of the figure, then in infinitive sentences the performer of the action, ie the active figure is assumed. Infinitive sentences cannot belong to impersonal constructions, because impersonal sentences are characterized not only by simplicity, but also by the fact that they lack a subject.

It is necessary to emphasize the need to take into account the meaning of a person in the predicates of impersonal sentences, because in modern linguistics the category of person is mainly interpreted as a category of predicative type, which is inherent in each sentence of language, based on the ontological nature of speech in general $^{2}$.

\section{Structural Paramenters of the Impersonal Sentences in Czech language}

Czech syntactists define an impersonal sentence as a simple syntactic construction with a predicative basis that expresses the action (being), state (sign) of reality regardless of or indirectly relative to the figure, the bearer of the state. The specificity of impersonal sentences in relation to other monosillabic sentences is defined by researchers of Czech syntax as a way of expressing an action or state as independent of the actor, the bearer of the state, which provides two plans: irrelevance to the subject of action, state and indirect relativity to it $^{3}$.

In scientific works on this problem, Czech linguists have consistently held the view that the main and indivisible component that organizes grammatical connections in an impersonal sentence and expresses its main meaning is the predicate. Minor members of the sentence, the necessity of which is justified in the sentence by the requirements of the predicate arising from its valence, create together with the predicate the main sentence structure or the minimum sentence structure, which qualifies as a relational sentence structure ${ }^{4}$. Comparison: Sněži (M. Majerová: 61); Prši (H. Pavlovská: 40); Šlo o peníze (V. Vančura: 21); Hrobníka bolelo skoro všude (B. Ř́ha: 75); Doma se nevařilo (M. Majerová: 115); Ráno mě bolí $v$ břiše (D. Šlosar: 61); Bývalo mu líto (P. Kles: 74); Včera pršselo (V. Vančura: 36); Podařilo se nám zastavit taxíka (I. Klíma: 88). Comparison in Ukrainian: Звечоріло (O. Honchar); Розвиднювалось

2 Мирченко М.В. Категория лица в семантико-синтаксической структуре предложения : дисс. ... канд. филол. наук. Киев, 1981. С. 2-3.

${ }^{3}$ Mluvnice češtiny. Skladba. Praha : Academia, 1987. Díl 3. S. 172-173.

${ }^{4}$ Havránek B., A. Jedlička. Česká mluvnice. Praha, 1981. S. 173-175. 
(A. Golovko); Надворі смеркалося (P. Myrnyi); Он незабаром буде світати (М. Kotsyubynsky); $У$ хаті все темнішало $i$ темнішало (M. Vovchok).

The vast majority of researchers rightly believe that the principle of systematization in the study of simple, in particular impersonal, sentences is the result of the method of syntactic-semantic modeling, associated with the establishment of sentence models as abstract syntactic patterns, which can be built separate minimum relatively complete sentences, and therefore the sentence model should include a minimum number of constitutive components 5 .

Researchers believe that at the abstract level of syntactic-semantic modeling the main types of minimal sentence structures are formed from the verb predicate and implementers of its functional-syntactic positions, which have the character of sentence members (regardless of their morphologicalsyntactic design.

Unfortunately, the question of sentence members, which should be included in the minimum sentence structure, is still debatable. Thus, L. Tenier, one of the founders of the linguistic theory of valence, dividing the members of the sentence into actants and sirconstants, included only the first in the structure of the valence model.

A similar view was held by a Slovak syntaxist E. Paulini, who was the first to justify the use of valence theory in Czech and Slovak grammar. E. Paulini on the basis of the analysis of full verbs managed to combine the semantic and formal side of the phenomenon, which he named as the direction of action. The researcher noted that action as a dynamic feature of an object in space does not exist independently, so it is necessary to determine or assign the object to which it is directed, based either on the position of the agent (performer) or a patient, and defines intention as a fact when the verb whether the predicate requires or does not require the expression of an agent or patient of its action.

J. Ruzhychka, developing E. Paulini's theory of intention, drew attention to its syntactic aspect, in particular to such points as the discrepancy between the intentional type and sentence structure and the possibility of modifying certain intentional types of verbs. A little later, the Czech syntaxists J. Bauer, M. Greple, and V. Schmilauer, mostly agreeing with the well-founded notions of valence theory and the expediency of its use in linguistic Slavic studies, noted that all obligatory components that have constitutive character should be considered valence-bound. The main intentional types of minimal sentence structures are constituted from the verb action and its participants participatory (functional-semantic positions, which have a generalized

${ }^{5}$ Běličová H. Semantická struktura věty a kategorie pádu. Praha, 1982. S. 10. 
character of agent, carrier of action or state, patient, adverbializer and qualifier ${ }^{6}$.

These observations also apply to Slavic one-syllable sentences of the verb type, which preserve the nature of the intentional verb action, the ability to open a certain number of functional-semantic positions to be filled by the corresponding participants.

As noted in linguistic bohemianism, intentional and valence structures correlate with each other, forming complex minimal sentence structures. The correlation of the components of valence and intentional structures with each other indicates a close connection between the semantic and formal-syntactic organization of the sentence. Accordingly, the violation of the direct correspondence between the components of intentional and valence structures involves modifications of the minimum sentence structures. In Czech syntax, morphological-syntactic implementations of the main valence types of minimal sentence structures and lexical-semantic implementations of the main intentional types of minimal sentence structures are consistently determined at a specific level of syntactic-semantic sentence modeling.

According to Slavic researchers, the establishment of qualitative and quantitative structural characteristics of sentence models in Slavic languages should take into account the morphological and categorical design of the components of minimal sentence structures, as some morphological categories are syntactically relevant and affect the establishment and distinction of models, for example, case category. noun, and others - noun categories of gender and number, verb categories of person, number, gender, type, method, time, etc. - only lead to intra-model changes, without violating the unity of the model.

Used together with prepositions and without them, case forms of nouns are the main means of realization and differentiation of minimal structures and their modifications, and the nominative case as a direct formalizes the left-handed component, and genitive, dative, accusative, instrumental and local as indirect - valid. An important element of the interaction-valence theory of sentence members is the fact that in addition to case and prepositional-case forms, adverbs, adjectives, infinitives and subjunctives of complex sentences can also take part in the design and distinction of structural models of a sentence ${ }^{7}$.

After all, the categorical nature of some statements about the special role of cases in the formation of minimal sentence structures is not always

Андерш Й.Ф. Типологія простих дієслівних речень у чеській мові в зіставленні з українською. Київ, 1987. С. 22.

7 Андерш Й.Ф. Типологія простих дієслівних речень у чеській мові в зіставленні з українською. Київ, 1987. С. 26. 
convincing, because the structural model can impose restrictions on specific lexical material that fills its functional and syntactic positions, in particular, for example, the verb promotes the formation of semantic groups. one or another case.

Such theoretical generalizations of Czech grammarians are consistent with the opinion of I.R. Vykhovanets, who, on the basis of the Ukrainian language, substantiates and defends the thesis that verbs are the main carriers of valence in a sentence, while other carriers of valence - adjectives, adverbs and nouns - acquire valence properties only in connection with the verb, ie due to their movement into the primary predicative position for the verb ${ }^{8}$.

Recall that in Czech and Ukrainian languages, as in other Slavic, semantic-syntactic valence of the predicate means its ability to combine with other words, to have a number of open positions that can or should be filled with units of the corresponding semantic nature, and the ability of the verb to set a certain number of functional-semantic positions for their participants to fill the action at the semantic-syntactic level - its intention, ie the predicate determines the quantitative composition of the components of the sentence and their semantic functions.

Based on the valence-intentional properties of predicate verbs, researchers determine a set of sentence models, or minimal sentence structures (základová větná struktura), which form minimal, but sufficient in structural and informative terms sentences.

According to most Slavic scholars (J.F. Andersh, G. Belichova, F. Danesh, I.R. Vykhovanets and others) it is advisable to distinguish two levels of syntactic-semantic modeling of the sentence, including impersonal - abstract and concrete: the first level highlights abstract valence and intentional types of minimal sentence structures, and the second - their specific morphological-syntactic and lexical-semantic realizations, ie specific structural and semantic models (types of basic vátných structures).

Our observations on the structural and semantic characteristics of singlesyllable impersonal sentences in the Czech language allowed us to identify the main features that determine this structural type of sentence among other single-syllable and the possibility of its modification. The most important structural feature of impersonal sentences in the Czech language is the presence of only one main predicative component, which subordinates the other components, if they are in the sentence, for example: Zdálo se (B. Říha: 144); Prší (H. Pavlovská: 40); Zetmělo se (R. Jesenská: 53); Sněži (M. Majerová: 61); Hř́malo (V. Vančura: 102); Tmělo se a tmělo (K. Sezima:127). Comparison Ukr.: Мрячило (O. Gonchar); Звечоріло (O. Honchar); Розвиднювалось (A. Golovko). Unlike other types of

${ }^{8}$ Вихованець I.Р. Граматика української мови. Синтаксис. Київ, 1993. С. 123. 
one-syllable sentences, such an impersonal structural-grammatical center does not allow the introduction of the second polar component into the structural scheme.

Our observations on the structural and semantic characteristics of singlesyllable impersonal sentences in the Czech language allowed us to identify the main features that determine this structural type of sentence among other single-syllable and the possibility of its modification. The most important structural feature of impersonal sentences in the Czech language is the presence of only one main predicative component, which subordinates the other components, if they are in the sentence, for example: Zdálo se (B. Říha: 144); Prši (H. Pavlovská: 40); Zetmělo se (R. Jesenská: 53); Sněži (M. Majerová: 61); Hřimalo (V. Vančura: 102); Tmělo se a tmělo (K. Sezima: 127). Comparison Ukr.: Мрячило (O. Gonchar); Звечоріло (O. Honchar); Розвиднювалось (A. Golovko). Unlike other types of one-syllable sentences, such an impersonal structural-grammatical center does not allow the introduction of the second polar component into the structural scheme.

In the linguistic literature it is noted that the superficial structure of an impersonal sentence in Slavic languages is determined by two positions the position of the main member and the position of the secondary member and respectively two members of the sentence - the main and secondary. The existing secondary member of an impersonal sentence extends the predicative core of the sentence or secondary members of the sentence, which are divided into determinant and adverbial secondary members ${ }^{9}$.

Analyzing the corresponding syntactic units in the Ukrainian language, I. R. Vykhovanets affirms that the position of the determinant in impersonal sentences is characterized by the connection with the transformation of a complex sentence by folding one of the predicative parts, and complicated by determinants impersonal sentence is a semantically complecated construction with two or more predicates.

In our opinion, the theoretical generalizations of the famous Ukrainian syntactist are fully consistent with the results of studies of Czech impersonal sentences, in which determinants are combined with the main member of an impersonal sentence by a weak subjunctive connection by means of adjoin, and the position of the determinant is mostly syntactic and analytical adverbs. After all, determinants in Czech, as well as in Ukrainian impersonal sentences do not have a fixed position and can indicate the characteristics of the subject. If there are several determinants, the position of each of them is determined by the proximity or remoteness from the main member of the impersonal sentence.

9 Вихованець І.Р., Городенська К.Г., Русанівський В.М. Семантико-синтаксична структура речення. Київ, 1983. С.6. 
It is known that the specificity of the subordinate connection in the Slavic languages is reflected by the strong nature of the connection with its typical form - management, which is manifested in the fact that the supporting component by its lexical and grammatical nature requires a dependent component in some form to reveal its content, ie the base component contains the control potential [264:17-18; 65:20-21]. Comparison: Zatmělo se jí v očich (L. Ziková: 22); Sklaplo mu v hlavě (K. Mašek: 70); Nachvíli jí blesklo mozkem (K. Sezima: 160). Comparison Ukr.: В голові йому немов світало (M. Kotsyubynsky).

The study of impersonal sentences against the background of other Czech monosyllabic structures revealed a strong nature of the subordinate connection in cases where the position of the dependent component is occupied by the accusative case. In this case, the semi-peripheral position is occupied by components that are combined not only with the reference component itself, but also with the words that depend on it. For example, in a sentence Množství jablek, broskví a mukyni strženo bylo se stromů tíhou a dozrálostí (J. Opolský: 235) the component se stromu depends on the complex Množství jablek, broskví a mukyní strženo bylo.

In the peripheral position of the dependent component of the phrase there is an instrumental case, which is combined with the base component together with the dependent words in the form of weak control. In the sentence Množství jablek, broskvi a mukyni strženo bylo se stromů tíhou a dozrálostí component tíhou a dozrálostí depends on the complex Množství jablek, broskví a mukyní strženo bylo se stromů.

The implementation of a weak subordinate connection in word-combinations with a projection on the structure of the Czech impersonal sentence occurs by means of concord, the choice of which is determined by morphological factors: komu se dostane čeho od koho [264:53]. Comparison: Vždyt’ se vám dostalo výhodného pozadí (F. Šrámek: 288). This phenomenon can be traced in other Slavic languages when the expressed adjective with syntactic forms of the genus, number and case of the adjective dependent member of the word-combination is combined with the base noun, and the forms of the genus, number and case of the adjective are determined by the forms of the genus, number and case of the base noun [65:22]. Comparison in Ukrainian: Одного разу почулося їи сюрчання польового коника (O. Honchar).

In Czech impersonal units, in addition to the main member, secondary members of the sentence (determinant and adverbial secondary member) in the positional structure of the sentence are also positions of the supporting member and indirect secondary member of the sentence, which do not change the qualitative structure of the impersonal sentence, changing it only quantitatively [312 13; 7:25]. The supporting members in the structure of an impersonal sentence are connected by a coherent connection, which does not 
make qualitative changes, but only spreads the sentence through the introduction of new members, homogeneous in form and grammar.

This feature of the structure of Czech impersonal sentences, obviously, can be qualified as common Slavic, as it can be traced in East Slavic languages, in particular in Ukrainian, when the indirect subjunctive is characterized by inequality of its combined sentence members, one of which (dependent) is subordinate to the basic, on the one hand, and through the mediation of the reference correlates with the predicative core of the impersonal sentence. The comparison is Czech Bylo mu uloženo vyplatit oslovenému dlůh, vlastně jen dvacet korun (V. Dyk: 262). Comparison in Ukrainian: Видано діарій письменника, тобто його щоденникові записи [65:16].

At the formal-grammatical level, the predicate in Czech impersonal sentences can be complicated by phase verbs. The predicative base necessarily includes a conjugative or auxiliary verb, although in determining the categorical affiliation of the main predicative member, predicative bases with proper impersonal and impersonal impersonal verbs, predicative adverbs, predicative forms on -no, -to, combinations of modal components with infinitive.

According to structural features, impersonal sentences of the Czech language are divided into simple, complex and compound predicative units. The main structural types of Czech impersonal sentences presented in the article take into account the valence of verb predicates, in particular those functional load of which can be traced both at the level of frequency of constructions in the analyzed texts and at the level of intentional parameters of predicative units.

Therefore, the structural model of the Czech impersonal sentence, in addition to the core, includes all the semantic components necessary for the realization of the communicative completeness of a particular impersonal unit without taking into account the species differentiation of predicates, because not always coincidence of structural characteristics.

At a specific level of syntactic-semantic modeling of a sentence, morphological-syntactic realizations of the main valence types of minimal sentence structures, ie structural models of a sentence, are determined.

Determination of structural models of sentences is carried out taking into account the peculiarities of morphological and categorical design of the components of minimal sentence structures. The fact is taken into account that different morphological categories take part in the design of the components of minimal sentence structures, some of which are syntactically relevant, and others only lead to intramodel changes without violating the unity of the model.

Basic elementary impersonal predicative units in the Czech language are constructions with the main member expressed by an impersonal verb or a 
personal verb used in an impersonal form. Such structures in which the verb predicate is self-sufficient, ie does not open any additional functionalsyntactic positions, in Czech linguistics are called structures with valencefree predicates (struktury s predikáty bezvalečními).

One of the characteristic structures of impersonal predicative units in the Czech language is the impersonal sentences $(12.5 \%$ of the total number of analyzed constructions). Such sentences have a stable and at the same time limited morphological expression, because the function of the main member in them is performed only by an impersonal verb - without the particle se or with this particle.

In the Czech language, impersonal verbs are characterized by a narrow paradigm in terms of modal and temporal characteristics: Svitá. Dosud ještě nesvitalo. Musí už svítat etc; in species oppositions: sněži - zasněží, therefore the number of impersonal verbs without the particle se is limited (sněžit, svitat, pršet etc.). This type of one-syllable sentences in the Czech language is the only sentence structure of the impersonal type, based on the avalence of the verb (structural model Vf imp); predicates here are usually verbs that call atmospheric phenomena Mrzlo, až praštělo; Venku sněží; To se prášil!; Zavři, táhne!

Such predicates do not require any direct action or intervention by any object. If we are talking about the subject, then it is mainly a carrier of inertial action, although from the standpoint of valence bohemians describe such structures as twofold. Comparison: Uhodilo - Uhodil blesk. Zatahuje se - Obloha se zatahuje. Rather, here you can predict the circumstance of the place, comparison: Odpoledne prši (Mája Z.); Smrákalo se, mžilo (B. Hrabal); Už svitalo (K. Sezima). Venku přestáválo pršet (O. Bočková). Comparison Ukr.: Без кіния мрячило (O. Honchar); Он незабаром буде світати (M. Kotsyubynsky).

In verbs denoting the motion of matter, alternatively, the possible spread of the structure due to the circumstances of the place, clarifying \&quot; kde \& quot: Prší-Venku prši - Do stanu prší. Na horách fouká - Od hor fouká. Tady práš́i - Práší se sem okny. Comparison Ukr.: В лісі зовсім затемніло (M. Kotsyubynsky Надворі забіліло (A. Golovko); У хаті все темнішало і темнішало (M. Vovchok). Important for the theory of impersonal sentence in the Czech language are the views on the problem of Czech grammarians F. Danes and Z. Glavsa, who believe that the use of circumstances in such a simple sentence model can not be qualified as a normative phenomenon. Therefore, such cases of using the circumstance in the actual impersonal sentences, in our opinion, are obligatory, because in the Czech literary language Táhne used only in combination Tady/pode dveře táhne etc.

The second group of impersonal sentences in the Czech language is formed by impersonal constructions built on the structural model $\mathrm{V}$ fimp refl, where the formative element is inverse verbs without constructive determinants. Unlike the first group of sentences, built in the Czech language on the 
structural model Vfimp, which is quantitatively limited, impersonal sentences with the particle se are widely represented in all Slavic languages, although the range of their semantic meanings is not wide - mostly an indication of weather, change of day, the value of success or failure and the state of beings, for example: Zetmélo se (R. Jesenská); Podařilo se (K. Sezima); Neozvalo se (V. Dyk); Myslilo se (O. Theer); Zdálo se (K. Mašek); Stalo se (J. Hilbert); Jelo se (J. Durych); Tvrdilo se (K. Sezima); Pílo se a jedlo (J. Durych); Podařilo se! (J. Opolský); Hrálo se (V. Dyk); Filmuje se (К. Čapek). Comparison in Ukrainian: Смеркалося (M. Kotsyubynsky); Як мається? (M. Kotsyubynsky); Почулося (I. Nechuy-Levytsky).

Such Czech impersonal sentences can be transformed into two-syllable constructions in which the verb-predicate is used without the particle se, losing the meaning of the generalized action, comparison: $O$ tom se ještě dodnes vypravuje - O tom ještě dodnes vypravují - Lidé/Všichni o tom ještě dodnes vypravuji. The possibility of such a transformation is explained by the fact that in the Czech language the reflexive form can be formed from almost any verb, including modal verbs moci, mit, smét, musit/muset.

Sentences in which the verb predicate reveals the positions of the object, the adverb, or both minor members are qualified in bohemianism as structures with valence predicates (struktury s predikáty valečnimi). They form a fairly large group of constructions in the Czech language (50.6\% of the total number of analyzed sentences) with verb predicates that express physical feelings, experiences, moods or mental state of a person and are represented by monovalent or divalent structural models. Such predicative units refer to an action when a person does not act as its direct performer, but rather experiences the action, and the fact of connection with a person of a certain event, mood or state always corresponds to one of the positions of the valence field, but never the position of the subject.

In the structural model of the impersonal sentence of the Czech language Vfimp - Adv the constitutive component is an adverb that has the value of the localizer of action (5.6\% of the total number of analyzed constructions). Such impersonal sentences indicate the localization of the action in a particular object or place. Accordingly, there are two versions of the model - ADV "kde", for example: Hučí v komíně (F. Šrámek); Straši v zámku (O. Theer); V podrostech harašilo (K. Sezima) and ADV"kam", for example: Nateklo do síně (V. Dyk); Zaklepano slabě na dveře (J. Hilbert); Uhodilo do stodoly (V. Dyk).

In the Czech language, the syntactic noun in the form of the genitive case is a mandatory component of the model is Vfimp - Sg (3.8\% of the total number of analyzed constructions), for example: Stačilo však jenom trochu sebevlády (F. Šrámek); Nezbývalo nic jiného než čekat (I.Klíma); Připadalo sněhu ale pozdéji se vyjasnilo (J. Durych). Researchers note that the number of Czech verbs that can act as an impersonal predicate of constructions with a genitive case is limited. In fact, these are verbs that have the meaning of increasing or decreasing the number, volume or size of something, such as 
ubývat, přibývat, napadat, prripadat. As our observations show, the meaning of complete, absolute absence can be expressed by specialized morphological means, in particular the use of a noun with a diminutive suffix in the form of the genitive case, comparison: Nebilo ani človićka (I. Klíma).

It is known that the analyzed type of impersonal sentences can be correlated with the corresponding Czech two-syllable constructions, comparison: Připadalo sněhu - Sníh připadal. The difference between these sentences is that impersonal construction takes as a special reading connected with more uncertainty, generalization of the concept which will be able to be a subject.

According to the structural model Vf imp refl - Sd in the Czech language a significant number of sentences is formed $(16.9 \%$ of the total number of analyzed constructions), for example: Mně se stalo! (J. Hilbert); Zdálo se mu (J. Hilbert); Nelíbilo se mi (J. Matějka); Připadalo jí (Jan z Wojkowiez); Pripadalo $m i$ (O. Theer). The object in the form of the dative case, used in an impersonal sentence that conveys the action or state of the object (person), is close to the nominal subject in two-part constructions, comparison: Rodiče mu zemřeli - (Jeho) rodiče zemřeli; Ztratilse mi pes Ztratil se mijj pes. In cases where the predicate expresses not physical but mental actions, the semantic difference between one-syllable impersonal and two-syllable personal sentences is minimal, the comparison: Spát se mi nechtělo - Nechtěl jsem spát; Nechtělo se mi věrit - Nechtěl jsem věrit; Chtělo se ji střašlivé zasmát - Chtěla střašlivé zasmát.

A constitutive component of another structural model Vf imp - Sa is the accusative case of a noun or pronoun in state predicates $(6.2 \%$ of the total number of analyzed constructions. Such a model forms sentences that express the physical or mental state of a person. For example: Mrazi ho (K. Sezima); Štvalo mne (O. Theer); Mrzelo mě, že s naši chystané cesty sešlo (I. Klíma); Mne kručelo (O. Bočková).

The accusative case, in contrast to the genitive, dative and instrumental cases, Czech syntaxists qualify as a peripheral morphological means of expression of the subject syntax, noting that the semantic variants of the accusative case can be replaced by syntagmatic, which, in turn, does not clearly define the place of accusative case on the axis of personality/impersonality. Therefore, the only function of the accusative case as one of the two object actants is the actant function, which is somehow caused by external action.

The study of the specifics of divalent structures of impersonal sentences in modern Slavic works on syntax is presented using a systematic approach to the study of linguistic phenomena, which involves the analysis of relevant syntactic units both at the level of language and at the level of speech. This allows us to identify models by which impersonal syntactic constructions are formed, anticipating their structural-semantic interaction. Thus, in the Czech language divalent structures are represented by structural models Vf imp - 
Sd - Adv; Vf imp refl - Sd - AdvQual; Vf imp - Sa - Adv; Vf imp - Si $\mathrm{Adv}$; $\mathrm{Vf}$ imp $-\mathrm{Sa}-\mathrm{Si}$ organizational center of which is predicate syntaxes with the semantics of the state, which, according to researchers, can indicate the proper-state and the improper-state.

According to our observations, in quantitative equivalent, divalent structures account for $18.1 \%$ of the total number of analyzed structures, and predicates that convey the value of physical, physiological and mental state of a man, in addition to the position of the carrier of this state open the position of the state object, physiological or mental state, and the position of the valence field coincides with the object of the place. Comparison: V hlaver se mu zamžilo (H. Malírová); Hrobníka bolelo skoro všude (B. Ríha); $V$ hlavě mu hučelo rychlými a bolestnými tepy (K. Čapek).

Researchers note that in the Czech language there is a large group of impersonal sentences (according to our observations 28.1\% of the total number of analyzed constructions), in which the verb být can act as a formal grammatical predicate. Like any other verb, the verb být in such sentences is a carrier of grammatical categories, but is not a real, "responsible" center of the sentence in the literal sense of the word, because the function of the semantic predicate is performed by the whole complex být + predicate, although in Czech the verb být does not always act only in the function of the verbconnection (terminologically - spona) as we have in impersonal constructions, and as stated in the syntactic studies of Czech linguists (B. Havránek, A. Jedlička). Comparison: Je student - Není student i Je mi lito - Není mi lito.

Sentences with the predicative center být + predicate in Slavic languages usually indicate static meanings. Thus, among the studied Czech impersonal sentences, sentences with the predicative center být + predicate indicate the characteristics of atmospheric phenomena: Bylo dusno, žrejmě na déšt' (I. Klíma); Venku pršelo a bylo dost chladno (P.Tigrid); Tady bylo spišs vlhko a dopoledne pršelo (H.Malírová); express a subjective-objective assessment of the situation or environment: Je pěkně (K. Mašek); Bylo tak ticho v domě a venku (Mája Z.); Zase bylo ticho (Bočková O.) or are used to indicate the physical or mental state of a person: Není vám nevolno? (K. Žák); Ráno jí bylo hůře (K. Sezima); Je-li vámteplo, odložte si kabát (H. Malířová).

Among the analyzed impersonal sentences of the Czech language with a compound predicative base, predicative units with the main member-verb in the form of an infinitive and the auxiliary verb být most often function, for example: Bylo mi často mírniti jeho prudký hněv (V. Vančura); Bylo cítit, že země chvěje (K. Sezima); Bylo slyšet výbuchy (I. Klíma); Nebylo těžké je nalézti (F. Šrámek); adjective forms on -no, -to together with the auxiliary verb být, for example: Pod stromy už plničko listů napadáno (Z. Maja); Bylo mi dovoleno býti hněvivým (V.Vančura); Mnoho spisovatelü bylo umlčeno a pronásledováno (P. Tigrid); Zaklepano slabě na dveře (J.Hilbert); adverbs together with the auxiliary verb být, for example: Tenkráte mu bylo úzko (P. Kles); A tady je dusno (I. Klíma); Nebylo nám volno v pařižském vzduchu 
(M. Jiránek); Ale bylo mu v ní úzko a smutno (H.Malírová); infinitive forms together with modal verbs and auxiliary verb být, for example: Kéz by bylo možno zapomenuti (Jiři K. ze Lvovic); Jak bylo možno jíti v náhlém šeru (V. Dyk); K vůli rodičù už bylo možno oko přimhouřit (K. Sezima).

\section{CONCLUSIONS}

Thus, the universal category "personality/impersonality" in the Czech language is based on the reflection of the extralinguistic semantic construct "absence or elimination of the subject (object, person) of action or state". The absence of the subject or its elimination is qualified as heterogeneous phenomena that arise at the conceptual level as a result of interaction of different tiers of the language system and affect the functional perspective and semantic-grammatical status of a single sentence as a syntactic unit.

In the conditions of impersonal functioning of personal verbs in the Czech language there is an implicit expression of the semantic subject, i.e. its successive reduction is traced both on formal-grammatical, and on semanticsyntactic levels of the sentence, and, consequently, impersonal use of personal verbs. units that differ from the relative two-syllable personal indirect expression or lack of expression, the implicitness of the subjective component.

The transition from the personal structure of the sentence to the impersonal in the Czech language occurs: 1) under the condition of vague perception and differentiation of the actor and action as a result of the total impression of the action and the actor - stmivá se; 2) in cases where the figure himself is an instrument of some force - uhodilo (bleskem); 3 ) in cases when instead of the figure the situation suggests what was not expressed in speech - horí, zvoní; 4 ) in cases when different modal verbs with the meaning of necessity, coercion form an impersonal sentence, which is aimed at everyone and no one Je nutno s tím zacházet opatrně; 5) in cases where there is a need to assess the internal psychological state - V̌sem bylo trapno.

The predicative base of impersonal sentences in the Czech language necessarily includes a full or auxiliary verb, which indicate the categorical characteristics of impersonality; structural and semantic features of impersonal units are most noticeable in sentences with proper and impersonal impersonal verbs, predicative adverbs, adjective forms on -no, -to and others.

\section{SUMMARY}

The present article under the title "Structural Model of an Impersonal Sentence of Czech Language" written by Kalenichenko Mariya deals with complex analysis of the impersonal sentences in Czech language. The subjectmatter of the research is an impersonal sentence in Czech language. The object of the research is the types and kinds of an impersonal sentence. The actuality is that in modern linguistic of Slav philology there is no unambiguous generally accepted definition of an impersonal sentence. The purpose of the paper is to present a special "impersonal" representation of the action or state. 
At the beginning it is pointed out the lack of personality as a categoric concept in Czech syntax and the methods and ways with the help of which the specificity of impersonal sentence as one of the most typical variety of Slav sentences of verbal type has been represented. It must be emphasized the need to take into account the meaning of a person in the predicates of impersonal sentences, because in modern linguistics the category of a person is mainly interpreted as a category of a predicative type, which is inherent in each sentence of the language, based on the ontological nature of speech in general.

To sum up structural and semantic parameters of Czech impersonal sentences have been investigated. The main patterns of their creation and specificity of their denotative characteristics have been defined as well. The main valency and intential types of Czech impersonal sentences have been established. A special interest is paid to the interconditionality of the structural-semantic parameters of the qualitative level of the lack of personality. The chosen manner of description of the syntactical units gives the possibility to determine the degree of participation of structure and semantics in the process of formation of such a phenomenon as the impersonal sentences.

\section{REFERENCES}

1. Андерш Й.Ф. Типологія простих дієслівних речень у чеській мові в зіставленні з українською. Київ, 1987. 190 с.

2. Вихованець І.Р., Городенська К.Г., Русанівський В.М. Семантико-синтаксична структура речення. Київ, 1983. 219 с.

3. Вихованець І.Р. Граматика української мови. Синтаксис. Київ, 1993. $368 \mathrm{c}$.

4. Мирченко М.В. Категория лица в семантико-синтаксической структуре предложения : дисс. ... канд. филол. наук. Киев, 1981. 227с.

5. Běličová H. Semantická struktura věty a kategorie pádu. Praha, 1982. $160 \mathrm{~s}$.

6. Havránek B., A. Jedlička. Česká mluvnice. Praha, 1981. 587 s.

7. Mluvnice češtiny. Skladba. Praha: Academia, 1987. Díl 3. 746 s.

Information about the author: Kalenychenko M. M., Candidate of Philological Sciences, Assistant Professor at the Slavic Languages Department Institute of Philology of Taras Shevchenko National University of Kyiv 14, Taras Shevchenko blvd, Kyiv, 01033, Ukraine 